\title{
An epidemic CC1-MRSA-IV clone yields false negative test results in molecular MRSA identification assays: a note of caution
}

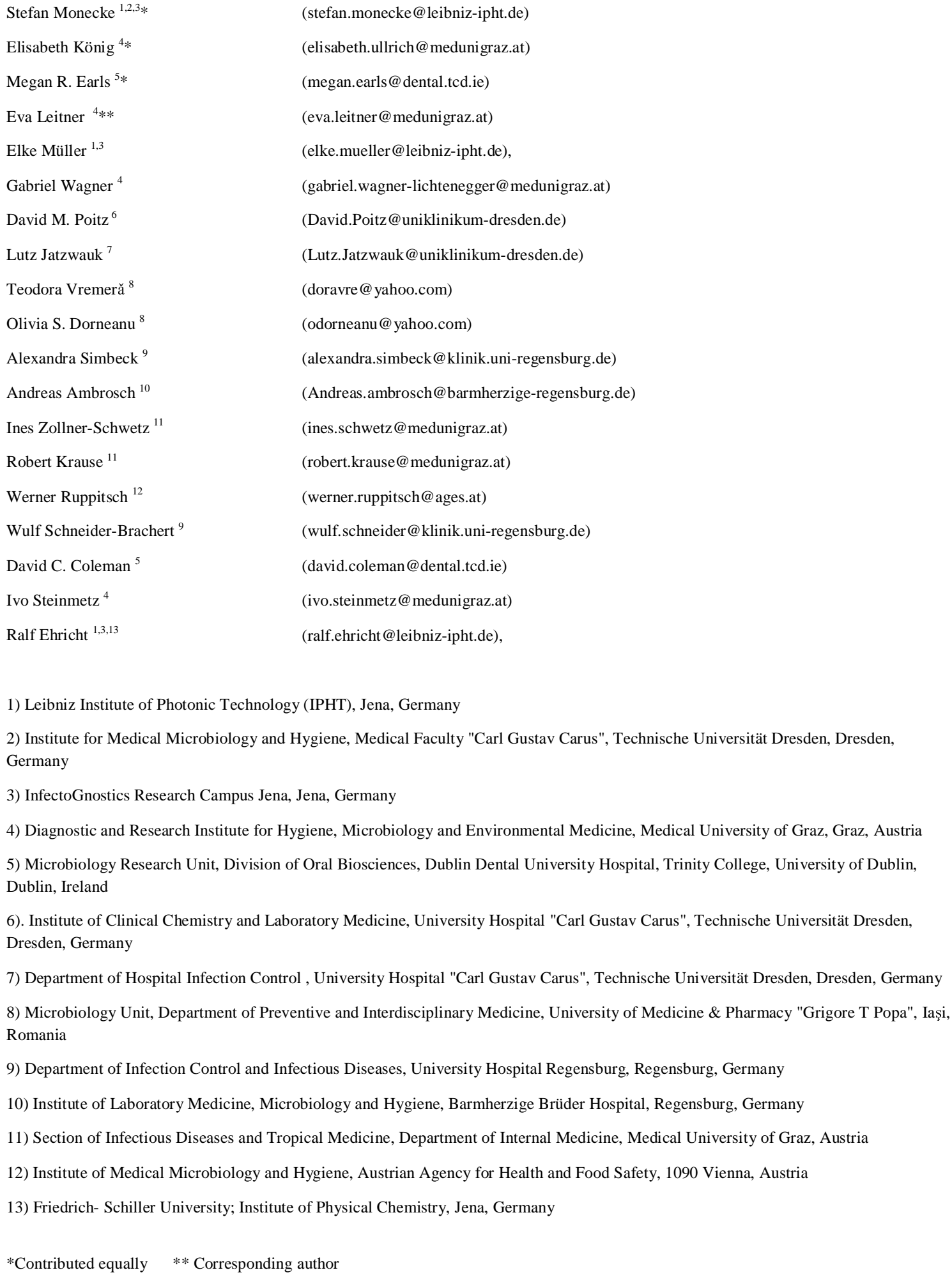


medRxiv preprint doi: https://doi.org/10.1101/2020.04.28.20083048; this version posted May 5, 2020. The copyright holder for this preprint (which was not certified by peer review) is the author/funder, who has granted medRxiv a license to display the preprint in perpetuity. It is made available under a CC-BY-NC-ND 4.0 International license.

Page 2

\section{ABSTRACT}

Background: A variety of rapid molecular PCR tests has been developed and commercialised that interrogate the junction site between the staphylococcal core genome, and the mobile genetic element (SCCmec) which harbours the gene responsible for methicillin-/beta-lactamresistance.

Aim: The purpose of the present study was to investigate why a clinical MRSA isolate yielded false negative test results with widely used, commercial orfX/SCCmec junction site PCR tests.

Methods: A collection of isolates that belonged to the same epidemic strain as the index isolate were investigated with commercial MRSA assays and all isolates were sequenced in order to explain this observation.

Results: It was found that isolates of the epidemic "European CC1-MRSA-IV" clone, which likely originated in South-Eastern Europe and subsequently spread to Western Europe, generally exhibit this behaviour. The failure of the assays was attributable to a characteristic large insertion in the orfX/SCCmec integration site presumably targeted by such tests. In contrast to MW2 (GenBank BA000033.2, a CC1 "USA400" strain which also harbours SCCmec IVa), the European CC1 clone harbours an insertion of $c a$. 5,350 nucleotides adjacent to $\operatorname{orf} X$. This sequence starts with a novel SCC terminal sequence alternate to $d c s$ and encodes six different hypothetical proteins (E7MHX1, ydiL2, C5QAP8, A8YYX4, npd-SCC, H4AYD7; nucleotide positions 280,690-286,024 of GenBank RBVO000005.1). An SCCmec element with the same insertion was previously found in a Staphylococcus epidermidis isolate (GenBank MH188467.1) suggesting transfer between staphylococcal species.

Conclusion: In order to ensure the reliability of molecular MRSA tests, it is vital to monitor the emergence of new SCCmec junction sites, not only in Staphylococcus aureus but also in coagulase-negative staphylococci. 
medRxiv preprint doi: https://doi.org/10.1101/2020.04.28.20083048; this version posted May 5, 2020. The copyright holder for this preprint (which was not certified by peer review) is the author/funder, who has granted medRxiv a license to display the preprint in perpetuity. It is made available under a CC-BY-NC-ND 4.0 International license.

Page 3

\section{INTRODUCTION}

Staphylococcus aureus is a Gram-positive bacterium that frequently colonises both humans and animals, mostly as a harmless commensal of the skin and mucous membranes, especially the nares. However, S. aureus can also be pathogenic, causing skin and soft tissue infections, pneumonia, meningitis, endocarditis, mastitis, osteomyelitis, toxic shock syndrome and sepsis. It can harbour numerous virulence-associated genes, many of which reside on mobile genetic elements (MGEs). Infections caused by S. aureus can be treated with a variety of antibiotics including flucloxacillin, cefazolin, co-trimoxazole, clindamycin, vancomycin, doxycycline amongst others, depending on the clinical presentation, severity and the susceptibility profile of the infecting strain.

Methicillin-resistant S. aureus (MRSA) were first identified almost 60 years ago and now constitute a major obstacle to therapy. Methicillin resistance is mediated by a modified penicillin binding protein ( $\mathrm{PBP}^{\prime}$ or $\left.\mathrm{PBP} 2 \mathrm{a}\right)$ that confers resistance to virtually all beta-lactam antibiotics, with the exception of some recently developed compounds such as ceftobiprole and ceftaroline. The genes $m e c A$ or $m e c C$ typically encode this property. The mecA gene is most commonly responsible for methicillin resistance in S. aureus and is localised on a variety of large and complex mobile genetic elements (MGEs), called staphylococcal cassette chromosome elements (SCCmec). The mecC gene is localised on an uncommon SCCmec element (type XI; $(1,2)$ ) and its presence is largely restricted to Western Europe where a distinct zoonotic connection to wildlife, especially hedgehogs, has been observed (3-5). Finally, there have been sporadic reports of plasmid-encoded genes, mecB (6) and mecD (7), which possibly originated in micrococci.

As therapy options for MRSA infections are limited, emphasis must be placed on infection prevention and control (IPC) measures including hand hygiene, the use of protective clothing and equipment and isolation of patients. Effective IPC implementation requires the rapid 
medRxiv preprint doi: https://doi.org/10.1101/2020.04.28.20083048; this version posted May 5, 2020. The copyright holder for this preprint (which was not certified by peer review) is the author/funder, who has granted medRxiv a license to display the preprint in perpetuity. It is made available under a CC-BY-NC-ND 4.0 International license .

detection of MRSA. Traditionally, this has been achieved using selective growth media containing methicillin or cefoxitin, salt and a chromogenic substrate (for an overview, see (8)). The latter facilitates the quick differentiation of MRSA from other, clinically less relevant staphylococcal species that may also harbour mec genes. While the use of chromogenic media is relatively inexpensive and convenient, plates must be incubated for 18$24 \mathrm{~h}$ before results are obtained. Considering that clinical judgements on whether to isolate a patient or to commence presumptive therapy with antibiotics that covers MRSA commonly require a much quicker decision, a variety of rapid molecular PCR tests has been developed and commercialised (9). These need to identify the presence of $m e c A$ and $m e c C$ and/or the presence of SCCmec elements together with a $S$. aureus-specific genetic marker(s). In addition, molecular tests should remain negative if the mec gene and/or the SCCmec element are present in another staphylococcal species that also might occur in the same sample. This can be achieved by placing one primer for the amplification reaction into the core chromosomal gene adjacent to the SCCmec element $(\operatorname{orf} X)$, which is present in all staphylococci, the sequence of which differs between different species. Importantly, the second primer cannot be placed into the mecA or mec $C$ sequence as the distance between orf $X$ and the mec gene is simply too large to be covered by a standard PCR. A "downstream constant segment" $(d c s)$ of SCC is widely distributed and highly conserved among MRSA strains, even among strains harbouring different types of SCCmec elements, making it an obvious choice for the placement of a second amplification primer. However, this approach can have drawbacks. Firstly, methicillin-susceptible $S$. aureus might yield a positive test result if they carry an SCC element without a mec gene, such as a dysfunctional remnant of SCCmec (10) or an element associated with fusidic acid resistance. Secondly, an MRSA strain with a non- $d c s$ downstream sequence might yield a negative result in such a test. In a central European setting, ca. 5\% of MRSA strains might carry one of as many as fourteen known different SCC terminal sequences alternate to $d c s$ (11). In order to ensure the reliability of 
medRxiv preprint doi: https://doi.org/10.1101/2020.04.28.20083048; this version posted May 5, 2020. The copyright holder for this preprint

(which was not certified by peer review) is the author/funder, who has granted medRxiv a license to display the preprint in perpetuity.

It is made available under a CC-BY-NC-ND 4.0 International license .

Page 5

PCR-based MRSA detection assays, newly obtained sequences of the orfX/SCCmec junction site should be monitored, and the emergence of new SCC terminal sequences should prompt an update to these tests. Thirdly, there are strains that are phenotypically susceptible to betalactam antibiotics (12) despite being positive in molecular tests targeting $m e c A$ and/or the orfX/SCCmec junction site.

The purpose of the present study was to investigate why a clinical isolate yielded false negative test results with a widely used, commercial orfX/SCCmec junction site PCR tests (Cepheid GeneXpert MRSA/SA BC and BD MAX Staph SR Assay), although it was confirmed to be MRSA by other means. It was found that isolates of the epidemic "European CC1-MRSA-IV" clone, which likely originated in South-Eastern Europe and subsequently spread to Western Europe $((13,14)$; for a detailed description, see also below), generally exhibit this behaviour. The failure of the assay was attributed to a characteristic large insertion in the orfX/SCCmec integration site presumably targeted by this test. 


\section{MATERIALS AND METHODS}

\section{Index case}

The index case of the present study was a 62-year-old man with bacteraemia caused by CC1MRSA which yielded a negative result using commercially available MRSA PCR systems in widespread use.

The index patient, who had metastasised lung cancer, was admitted to the Department of Internal Medicine, Medical University of Graz (Austria) with suspected pneumonia, and amoxicillin/clavulanic acid therapy was started. Blood cultures, incubated in an automated BACTEC system (Becton Dickinson; Heidelberg, Germany/Franklin Lakes, NJ, USA) became positive within one day. The organism was identified as $S$. aureus directly from positive blood culture bottles by peptide nucleic acid fluorescence in situ hybridisation (PNA FISH, AdvanDx, Woburn, MA, USA). The S. aureus isolate from one blood culture bottle (Graz_511421-19) was investigated by using the GeneXpert MRSA/SA BC PCR assay (Cepheid, Sunnyvale, CA, USA) in order to identify S. aureus/MRSA. Simultaneously, rapid antimicrobial susceptibility testing (RAST) was performed according to EUCAST guidelines $(15,16)$. The GeneXpert test was negative for MRSA but RAST revealed cefoxitin resistance after six hours of incubation. Additional antimicrobial susceptibility testing (Vitek2, bioMérieux, Marcy-l'Étoile, France) was performed confirming that it was indeed an MRSA isolate. Another molecular MRSA detection assay, BD MAX ${ }^{\mathrm{TM}}$ StaphSR assay (Becton Dickinson) was performed; it also yielded a negative result. Microarray-based characterisation with the S. aureus Genotyping Kit 2.0 (Abbott [Alere Technologies GmbH], Jena, Germany; see below) detected mecA, confirming the disk diffusion result for MRSA, and assigned the isolate to CC1-MRSA-IV. 
medRxiv preprint doi: https://doi.org/10.1101/2020.04.28.20083048; this version posted May 5, 2020. The copyright holder for this preprint (which was not certified by peer review) is the author/funder, who has granted medRxiv a license to display the preprint in perpetuity. It is made available under a CC-BY-NC-ND 4.0 International license.

Initially, before there was evidence for an MRSA infection, the patient's condition improved under beta-lactam treatment, and therapy was changed to flucloxacillin and fosfomycin. One day later, after antimicrobial susceptibility testing confirmed MRSA with susceptibility to fosfomycin and daptomycin, the treatment was modified and flucloxacillin replaced by daptomycin in addition to fosfomycin. Despite the fact that daptomycin has no pulmonary activity, alternative substances like vancomycin or linezolid were contraindicated due to nephro- and myelotoxicity. Fifth generation cephalosporins were not available. The patient died a few days later because of tumour progression.

The index isolate was identified as European CC1-MRSA-IV using DNA microarray profiling and whole-genome sequencing (see below).

\section{Additional CC1-MRSA-IV isolates investigated}

Beside the index case, another 38 additional isolates of the European CC1-MRSA-IV clone were investigated.

Ten Romanian CC1-MRSA-IV isolates were recovered between 2007 and 2010, during routine microbiological diagnostics in the Sfanta Parascheva Hospital for Infectious Diseases in Iasi, a 300-bed tertiary centre in North-Eastern Romania, where European CC1-MRSA-IV appears to be common (17).

Four isolates were recovered from diagnostic or screening procedures at the Medical Faculty of Dresden, a 1,200-bed tertiary care hospital in South-Eastern Germany. In Dresden, European CC1-MRSA-IV is very rare, with only six isolates being identified at the University Hospital among 1,752 isolates characterised by microarray profiling between 2000 and 2020 ((11) and unpublished data). In addition to European CC1-MRSA-IV isolates, four control strains were included in this study (see Table 1). Controls were assigned by microarray profiling (see below) to epidemic strains that are or were prevalent locally, or that belonged to 
medRxiv preprint doi: https://doi.org/10.1101/2020.04.28.20083048; this version posted May 5, 2020. The copyright holder for this preprint (which was not certified by peer review) is the author/funder, who has granted medRxiv a license to display the preprint in perpetuity. It is made available under a CC-BY-NC-ND 4.0 International license.

another CC1-MRSA strain (isolate \#220663). In addition, fully sequenced reference strains MU50, MW2, N315 and USA300-FPR3757 were also included as controls.

Nineteen Bavarian isolates recovered at the University Medical Centre in Regensburg between 2010 and 2019 were included, along with five isolates from other tertiary care centres in Bavaria. In Bavaria, the European CC1-MRSA-IV strain appears to be common. At the University Medical Centre in Regensburg, retrospective microarray profiling-based typing of 3,067 isolates revealed a clear increase in the prevalence of this strain. It accounted for $<1 \%$ of typed MRSA between 2010 and 2013, but reached a prevalence of $9.4 \%$ (26 out of 277) in 2019, being the third most common strain (behind CC5-MRSA-II and CC398-MRSA$\mathrm{V} / \mathrm{VT})$ at that centre.

All study isolates were preserved at $-80^{\circ} \mathrm{C}$ in cryovials following identification as MRSA, and molecular typing was performed retrospectively by microarray profiling. 
Table 1:

MRSA strains and isolates investigated in the present study and their detection using commercially available orfX/SCCmec junction site assays.

\begin{tabular}{|c|c|c|c|c|c|}
\hline Isolate & Strain affiliation (according to microarray) & SCCmec element & Origin & BD MAX results & GeneXpert results \\
\hline Graz_511421-19 (index case) & CC1-MRSA-IV (PVL-neg., aphA3/sat-positive) & SCCmec IVa with insertion & Austria, 2019 & NEGATIVE (G) & NEGATIVE (2 x BC; G) \\
\hline Dresden-94757 & CC1-MRSA-IV (PVL-neg., aphA3/sat-positive) & SCCmec IVa with insertion & Saxony, 2010 & NEGATIVE (D, G) & N/A \\
\hline Dresden-94758 & CC1-MRSA-IV (PVL-neg., aphA3/sat-positive) & SCCmec IVa with insertion & Saxony, 2014 & $\operatorname{NEGATIVE}(\mathrm{D}, \mathrm{G})$ & N/A \\
\hline Dresden-94759 & CC1-MRSA-IV (PVL-neg., aphA3/sat-positive) & SCCmec IVa with insertion & Saxony, 2009 & NEGATIVE (D, G) & N/A \\
\hline Dresden-94760 & CC1-MRSA-IV (PVL-neg., aphA3/sat-positive) & SCCmec IVa with insertion & Saxony, 2010 & $\operatorname{NEGATIVE}(\mathrm{D}, \mathrm{G})$ & N/A \\
\hline Iasi-95033 & CC1-MRSA-IV (PVL-neg., aphA3/sat-positive) & SCCmec IVa with insertion & Romania, 2009 & NEGATIVE (D, G) & N/A \\
\hline Iasi-95034 & CC1-MRSA-IV (PVL-neg., aphA3/sat-positive) & SCCmec IVa with insertion & Romania, 2009 & NEG. (D)/AMBIGUOUS (G)* & N/A \\
\hline Iasi-95035 & CC1-MRSA-IV (PVL-neg., aphA3/sat-positive) & SCCmec IVa with insertion & Romania, 2009 & NEG. (D)/AMBIGUOUS (G)* & N/A \\
\hline Iasi-95037 & CC1-MRSA-IV (PVL-neg., aphA3/sat-positive) & SCCmec IVa with insertion & Romania, 2009 & $\operatorname{NEGATIVE}(\mathrm{D}, \mathrm{G})$ & N/A \\
\hline Iasi-95038 & CC1-MRSA-IV (PVL-neg., aphA3/sat-positive) & SCCmec IVa with insertion & Romania, 2009 & NEGATIVE(D, G) & N/A \\
\hline Iasi-95039 & CC1-MRSA-IV (PVL-neg., aphA3/sat-positive) & SCCmec IVa with insertion & Romania, 2009 & NEG. (D)/AMBIGUOUS (G)* & N/A \\
\hline Iasi-95040 & CC1-MRSA-IV (PVL-neg., aphA3/sat-positive) & SCCmec IVa with insertion & Romania, 2009 & $\operatorname{NEGATIVE}(\mathrm{D}, \mathrm{G})$ & N/A \\
\hline Iasi-95041 & CC1-MRSA-IV (PVL-neg., aphA3/sat-positive) & SCCmec IVa with insertion & Romania, 2009 & $\operatorname{NEGATIVE}(\mathrm{D}, \mathrm{G})$ & N/A \\
\hline Iasi-174752 & CC1-MRSA-IV (PVL-neg., aphA3/sat-positive) & SCCmec IVa with insertion & Romania, 2010 & $\operatorname{NEGATIVE}(\mathrm{D}, \mathrm{G})$ & N/A \\
\hline Iasi-176047 & CC1-MRSA-IV (PVL-neg., aphA3/sat-positive) & SCCmec IVa with insertion & Romania, 2009 & NEGATIVE (D, G) & N/A \\
\hline Bavaria-0643 & CC1-MRSA-IV (PVL-neg., aphA3/sat-positive) & SCCmec IVa with insertion & Bavaria, 2018 & N/A & POSITIVE (SSTI; R) \\
\hline Bavaria-0824 & CC1-MRSA-IV (PVL-neg., aphA3/sat-positive) & SCCmec IVa with insertion & Bavaria, 2015 & N/A & POSITIVE (SSTI; R) \\
\hline Bavaria-1185 & CC1-MRSA-IV (PVL-neg., aphA3/sat-positive) & SCCmec IVa with insertion & Bavaria, 2018 & N/A & POSITIVE (SSTI; R) \\
\hline Bavaria-1274 & CC1-MRSA-IV (PVL-neg., aphA3/sat-positive) & SCCmec IVa with insertion & Bavaria, 2014 & N/A & POSITIVE (SSTI; R) \\
\hline Bavaria-1537 & CC1-MRSA-IV (PVL-neg., aphA3/sat-positive) & SCCmec IVa with insertion & Bavaria, 2013 & N/A & POSITIVE (SSTI; R) \\
\hline Bavaria-1780 & CC1-MRSA-IV (PVL-neg., aphA3/sat-positive) & SCCmec IVa with insertion & Bavaria, 2013 & N/A & POSITIVE (SSTI; R) \\
\hline Bavaria-1962 & CC1-MRSA-IV (PVL-neg., aphA3/sat-positive) & SCCmec IVa with insertion & Bavaria & N/A & POSITIVE (SSTI; R) \\
\hline Bavaria-2102 & CC1-MRSA-IV (PVL-neg., aphA3/sat-positive) & SCCmec IVa with insertion & Bavaria, 2019 & N/A & POSITIVE (SSTI; R) \\
\hline Bavaria-2220 & CC1-MRSA-IV (PVL-neg., aphA3/sat-positive) & SCCmec IVa with insertion & Bavaria & N/A & POSITIVE (SSTI; R) \\
\hline
\end{tabular}




\begin{tabular}{|c|c|c|c|c|c|}
\hline Isolate & Strain affiliation (according to microarray) & SCCmec element & Origin & BD MAX results & GeneXpert results \\
\hline Bavaria-2312 & CC1-MRSA-IV (PVL-neg., aphA3/sat-positive) & SCCmec IVa with insertion & Bavaria & N/A & \multirow{2}{*}{$\begin{array}{l}\text { POSITIVE (SSTI; R) } \\
\text { POSITIVE (SSTI; R) }\end{array}$} \\
\hline Bavaria-2360 & CC1-MRSA-IV (PVL-neg., aphA3/sat-positive) & SCCmec IVa with insertion & Bavaria & N/A & \\
\hline Bavaria-2391 & CC1-MRSA-IV (PVL-neg., aphA3/sat-positive) & SCCmec IVa with insertion & Bavaria, 2018 & N/A & POSITIVE (SSTI; R) \\
\hline Bavaria-2483 & CC1-MRSA-IV (PVL-neg., aphA3/sat-positive) & SCCmec IVa with insertion & Bavaria, 2019 & N/A & POSITIVE (SSTI; R) \\
\hline Bavaria-2535 & CC1-MRSA-IV (PVL-neg., aphA3/sat-positive) & SCCmec IVa with insertion & Bavaria, 2019 & N/A & POSITIVE (SSTI; R) \\
\hline Bavaria-2584 & CC1-MRSA-IV (PVL-neg., aphA3/sat-positive) & SCCmec IVa with insertion & Bavaria, 2019 & N/A & POSITIVE (SSTI; R) \\
\hline Bavaria-2585 & CC1-MRSA-IV (PVL-neg., aphA3/sat-positive) & SCCmec IVa with insertion & Bavaria, 2019 & N/A & POSITIVE (SSTI; R) \\
\hline Bavaria-2588 & CC1-MRSA-IV (PVL-neg., aphA3/sat-positive) & SCCmec IVa with insertion & Bavaria, 2019 & N/A & POSITIVE (SSTI; R) \\
\hline Bavaria-2596 & CC1-MRSA-IV (PVL-neg., aphA3/sat-positive) & SCCmec IVa with insertion & Bavaria, 2019 & N/A & POSITIVE (SSTI; R) \\
\hline Bavaria-2618 & CC1-MRSA-IV (PVL-neg., aphA3/sat-positive) & SCCmec IVa with insertion & Bavaria, 2012 & N/A & POSITIVE (SSTI; R) \\
\hline Bavaria-3012 & CC1-MRSA-IV (PVL-neg., aphA3/sat-positive) & SCCmec IVa with insertion & Bavaria, 2011 & N/A & POSITIVE (SSTI; R) \\
\hline Bavaria-3254 & CC1-MRSA-IV (PVL-neg., aphA3/sat-positive) & SCCmec IVa with insertion & Bavaria, 2010 & N/A & POSITIVE (SSTI; R) \\
\hline Bavaria-3702 & CC1-MRSA-IV (PVL-neg., aphA3/sat-positive) & SCCmec IVa with insertion & Bavaria, 2019 & N/A & POSITIVE (SSTI; R) \\
\hline Bavaria-3741 & CC1-MRSA-IV (PVL-neg., aphA3/sat-positive) & SCCmec IVa with insertion & Bavaria, 2019 & N/A & POSITIVE (SSTI; R) \\
\hline Bavaria-3784 & CC1-MRSA-IV (PVL-neg., aphA3/sat-positive) & SCCmec IVa with insertion & Bavaria, 2019 & N/A & POSITIVE (SSTI; R) \\
\hline Dresden-220663 & CC1-MRSA-IV, (PVL-neg., aphA3/sat-negative) & SCCmec IVa (as in MW2) & Saxony, 2007 & POSITIVE (D) & N/A \\
\hline Dresden-124288 & CC22-MRSA-IV (Barnim/UK EMRSA-15) & SCCmec IVh/j & Saxony & POSITIVE (D) & N/A \\
\hline Dresden-124289 & CC22-MRSA-IV (Barnim/UK EMRSA-15) & $\mathrm{SCCmec} \mathrm{IVh/j}$ & Saxony & POSITIVE (D) & N/A \\
\hline Dresden-124281 & CC45-MRSA-IV (Berlin EMRSA) & SCCmec IVa & Saxony & POSITIVE (D) & N/A \\
\hline MU50 & CC5-MRSA-II (New York/Japan Clone) & SCCmec II & $\begin{array}{l}\text { Japan (sequenced } \\
\text { reference strain) }\end{array}$ & POSITIVE (D) & N/A \\
\hline MW2 & CC1-MRSA-IV (PVL-pos. USA400) & SCCmec IVa & $\begin{array}{l}\text { USA (sequenced } \\
\text { reference strain) }\end{array}$ & POSITIVE (D) & N/A \\
\hline N315 & CC5-MRSA-II (New York/Japan Clone) & SCCmec II & $\begin{array}{l}\text { Japan (sequenced } \\
\text { reference strain) }\end{array}$ & POSITIVE (D) & N/A \\
\hline USA300-FPR3757 & CC8-MRSA-[IVa+ACME1] (PVL+), USA300 & $\mathrm{SCC}[$ mec IVa+ACME $1+\mathrm{Cu}]$ & $\begin{array}{l}\text { USA (GenBank } \\
\text { CP000255.1) }\end{array}$ & POSITIVE (D) & N/A \\
\hline
\end{tabular}

D, G, and R indicate that assays were performed in Dresden, Graz and Regensburg, respectively. BC, GeneXpert MRSA/SA BC. SSTI, GeneXpert MRSA/SA SSTI. N/A, not available/not performed.

*AMBIGUOUS, weak signal observed at $\mathrm{Ct}>35$ 


\section{Cepheid GeneXpert}

The index specimen from a positive blood culture was tested with the with the Cepheid GeneXpert system using the MRSA/SA BC assay (Lot. No. 1000148707). It was later retested with another lot of the same assay (Lot no. 1000179462). Further investigations on GeneXpert MRSA/SA BC were not possible due to restricted laboratory capacities during the influenza season and the SARS-CoV-2 pandemic.

Twenty-four Bavarian isolates were tested in Regensburg with the Cepheid GeneXpert MRSA/SA SSTI assay (Lot no. 1000180532). It was used according to manufacturer's instructions starting from pure overnight cultures on CBA.

\section{BD MAX}

The index isolate was tested in Graz using the BD MAX Staph SR assay (Ref.: 443419; Lot no. 9303156). Additional isolates as well as control strains (see above and Table 1) were grown overnight on Columbia Blood Agar (CBA) and sent for processing to the laboratories in Graz and Dresden where the BD MAX Staph SR Assay (Graz, Lot no. 9303156; Dresden, Lot no. K55928980720210312) was used according to the manufacturer's instructions.

\section{Microarray-based molecular characterisation}

Genotyping of all strains was performed using the S. aureus Genotyping Kit 2.0 (Abbott [Alere Technologies $\mathrm{GmbH}]$ ). The microarray-based assay covers 333 different targets related to approximately 170 different genes and their allelic variants. The list of target genes as well as sequences of probes and primers have been described in detail previously along with all relevant protocols (18). 
medRxiv preprint doi: https://doi.org/10.1101/2020.04.28.20083048; this version posted May 5, 2020. The copyright holder for this preprint (which was not certified by peer review) is the author/funder, who has granted medRxiv a license to display the preprint in perpetuity. It is made available under a CC-BY-NC-ND 4.0 International license.

Briefly, S. aureus was cultivated and harvested on CBA. Subsequently, DNA extraction was performed with an enzymatic combination of lysis enzymes and buffer from the S. aureus Genotyping Kit 2.0 kit and Qiagen DNA extraction columns (Qiagen, Hilden, Germany), according to the manufacturers' instructions. Linear amplification was performed using one specific primer per target. During amplification, biotin-16-dUTP was incorporated into amplicons. After incubation and several washing steps, hybridisation to the probes on the array was detected using streptavidin horseradish peroxidase that caused local precipitation at the spot where the specific amplicon was bound to the probe. Microarrays were photographed and analysed with a designated reader and software (IconoClust, Abbott (Alere Technologies $\mathrm{GmbH})$ ). Array profiling permits rapid isolate characterisation, detects the presence or absence of certain genes or alleles, automatically compares query isolates to a database of existing patterns, and assigns isolates to clonal complexes, known strains and SCCmec types.

\section{Whole-genome sequencing}

All isolates underwent whole-genome sequencing (WGS). Genomic DNA was extracted as detailed above for microarray-based molecular characterisation, and its quality was assessed as previously described (19). The Nextera DNA Flex Library Preparation Kit (Illumina, Eindhoven, The Netherlands) was used according to the manufacturer's instructions and libraries underwent paired-end sequencing using the 500-cycle MiSeq Reagent Kit v2 (Illumina). Libraries were scaled to exhibit at least 50-fold coverage and the quality of each sequencing run was assured following cluster density and Q30 assessment. Raw sequence reads were trimmed using fastp version 0.19.11 (20). Trimmed sequence read sets underwent de novo assembly using SPAdes version v3.9.1 (21) and all contigs under 1,000 bp were removed. 


\section{RESULTS}

\section{Cepheid GeneXpert tests and BD MAX}

Test results are provided in detail in Table 1.

Testing of the index MRSA isolate with two different lots of the GeneXpert MRSA/SA BC assay yielded negative results. However, the GeneXpert MRSA/SA SSTI assay correctly identified 24 European CC1-MRSA-IV isolates as MRSA.

The BD MAX assay system failed to identify isolates $(\mathrm{n}=15)$ of the European CC1-MRSAIV clone although control reference MRSA strains handled in parallel were correctly identified.

\section{Description of the European CC1 strain}

Microarray profiling and WGS analysis showed that the index MRSA isolate (Graz_51142119) belonged to a PVL-negative CC1-MRSA-IV clone previously described as "European CC1-MRSA-IV" $(13,14,17)$. This clone has been identified in Romania, Ireland and Germany $(13,14,17)$ and is represented by a published genome sequence (RBVO00000000.1; (14)).

European CC1-MRSA-IV isolates typically exhibit sequence type (ST) 1 (1-1-1-1-1-1-1) or its single locus variant ST4110 (1-1-1-1-1-1-558), and spa type t127 (07-23-21-16-34-33-13) or to related types such as t386 (07-23-13) or t13790 (07-23-21-16-34-33-34-34-33-34).

This clone is resistant to beta-lactam antimicrobials due to a functional mecA encoded on an SCCmec IV element (see below). It is usually resistant to erythromycin and clindamycin $(e r m C)$, tetracycline $(t e t K)$, as well as to kanamycin and neomycin (aphA3, accompanied by 
medRxiv preprint doi: https://doi.org/10.1101/2020.04.28.20083048; this version posted May 5, 2020. The copyright holder for this preprint (which was not certified by peer review) is the author/funder, who has granted medRxiv a license to display the preprint in perpetuity. It is made available under a CC-BY-NC-ND 4.0 International license.

$a a d E$ and sat). Some isolates of this clone also carry aacA-aphD and are resistant to gentamicin. This was not the case for the index isolate from Graz. A particular variant of this clone from Ireland is resistant to mupirocin (mupR) and quaternary ammonium compounds such as chlorhexidine due to the presence of a plasmid encoding iles $2 / m u p R$ and qacA, as previously described (14). Fusidic acid resistance has not yet been detected in this epidemic

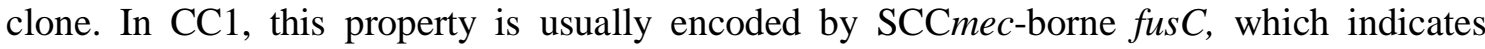
affiliation to other CC1 strains (of Middle Eastern or Southern Hemisphere background); and fusB/far-1 was not detected in isolates tested hitherto.

European CC1-MRSA-IV is PVL-negative and only very rarely carries supplementary enterotoxin genes (sek/seq) in addition to seh that is ubiquitously present in $\mathrm{CC} 1$.

\section{Description of the SCCmec element of the European CC1 strain}

The SCCmec element sequences of the European CC1-MRSA-IV clone were essentially identical in all study isolates as well as in the previously sequenced Irish isolate (GenBank RBVO). Minor polymorphisms were noted within $d r u$ and within the region between Q2FKL7 and Q8VUV8. These were not relevant for the present study, and can be considered random duplications/deletions, or possibly even as assembly artefacts.

This CC1-MRSA strain has an SCCmec IVa element. In contrast to MW2-like SCCmec IVa however, it harbours an insertion of ca. 5,350 nucleotides, adjacent to orfX. This sequence starts with a novel SCC terminal sequence alternate to dcs ("SCCterm 15"; see below) and encodes six different hypothetical proteins (E7MHX1, ydiL2, C5QAP8, A8YYX4, npd, H4AYD7; nucleotide positions 280,690-286,024 of GenBank RBVO000005.1). Compared to MW2 (BA000033.2), this insertion replaces $d c s$ and Q9XB68-dcs, and removes the larger part (212 of $240 \mathrm{nt})$ of the gene encoding hypothetical protein, Q7A213. 
medRxiv preprint doi: https://doi.org/10.1101/2020.04.28.20083048; this version posted May 5, 2020. The copyright holder for this preprint (which was not certified by peer review) is the author/funder, who has granted medRxiv a license to display the preprint in perpetuity. It is made available under a CC-BY-NC-ND 4.0 International license.

Page 15

The entire gene content of the SCCmec IV element is listed in Table 2, and Figure 1 provides a schematic representation of the MGE, including a comparison to MW2 (BA000033.2) and to the sequence of an S. epidermidis composite SCCmec element (see below). 
Table 2: Genes in the variant SCCmec IVa element of the European CC1-MRSA-IV strain.

\begin{tabular}{|c|c|c|c|c|c|}
\hline Gene ID & $\begin{array}{l}\text { Gene ID/definition of gene product and comments } \\
\text { (see also annotation of MH188467.1) }\end{array}$ & Orientation & $\begin{array}{l}\text { Locus tag in MW2 } \\
\text { (BA000033.2) }\end{array}$ & Coordinates in GenBank RBVO & $\begin{array}{l}\text { Coordinates in Iasi- } \\
95037 \text { (MT380478) }\end{array}$ \\
\hline $\operatorname{orf} X$ & 23S rRNA methyltransferase & & MW0024 & RBVO01000005.1; pos. 280209 to 280689 & \\
\hline sRNA6 & Antisense RNA associated with orf $X$ & & N/A & RBVO01000005.1; pos. 280389 to 280673 & \\
\hline DR_SCC & Direct repeat of SCC, to $19 \mathrm{nt}$ of the $3^{\prime}$ end of the coding sequence of orf $X$ & & N/A & RBVO01000005.1; pos. 280670 to 280689 & pos. 1 to 19 \\
\hline sccterm15 & SCC-terminal sequence adjacent to $\operatorname{orf} X$, and alternate to $d c s$, see Discussion & & Not present & RBVO01000005.1; pos. 280689 to 280912 & pos. 20 to 242 \\
\hline E7MHX1 & Transcription regulator & FORWARD & Not present & RBVO01000005.1; pos. 280912 to 281239 & pos. 243 to 569 \\
\hline ydiL2 & Hypothetical protein/putative membrane peptidase, associated with SCC elements & FORWARD & Not present & RBVO01000005.1; pos. 281275 to 282109 & pos. 606 to 1439 \\
\hline C5QAP8-M299 & Hypothetical protein & FORWARD & Not present & RBVO01000005.1; pos. 282794 to 283568 & pos. 2125 to 2898 \\
\hline A8YYX4 & Hypothetical protein & REVERSE & Not present & RBVO01000005.1; pos. 283805 to 284144 & pos. 3136 to 3474 \\
\hline npd-SCC & Enoyl-[acyl-carrier-protein] reductase-like protein & REVERSE & Not present & RBVO01000005.1; pos. 284329 to 285400 & pos. 3660 to 4730 \\
\hline H4AYD7-trunc & Transcriptional regulator, LysR family & TRUNCATED & Not present & RBVO01000005.1; pos. 285412 to 286024 & pos. 4743 to 5354 \\
\hline Q7A213-trunc & $\begin{array}{l}\text { Putative protein; it comprises the inverted repeat of IS431. In MW2 it is not } \\
\text { truncated and comprises } 240 \mathrm{nt} .\end{array}$ & TRUNCATED & MW0026 & RBVO01000005.1; pos. 286024 to 286052 & pos. 5355 to 5382 \\
\hline IR_IS431 & Inverted repeat of IS431 & TRUNCATED & N/A & RBVO01000005.1; pos. 286024 to 286040 & pos. 5355 to 5370 \\
\hline tnpIS431 & Transposase for IS431 & REVERSE & MW0027 & $\begin{array}{l}\text { RBVO01000005.1; pos. } 286083 \text { to end of } \\
\text { contig (pos. 286184) (partial) }\end{array}$ & pos. 5414 to 6088 \\
\hline Teg143 & Trans-encoded RNA associated with tnpIS431(22) & & N/A & RBVO01000003.1; pos. 203 to 237 & pos. 6119 to 6152 \\
\hline \multirow{2}{*}{$\begin{array}{l}\text { IR_IS431 } \\
\text { mvaS-SCC }\end{array}$} & Inverted repeat of IS431 & TRUNCATED & N/A & RBVO01000003.1; pos. 213 to 229 & pos. 6129 to 6144 \\
\hline & Truncated HMG-CoA synthase & FORWARD & MW0028 & RBVO01000003.1; pos. 245 to 598 & pos. 6161 to 6513 \\
\hline Q5HJW6 & Hypothetical protein & FORWARD & N/A & RBVO01000003.1; pos. 695 to 1046 & pos. 6611 to 6841 \\
\hline dru & SCC direct repeat units & TRUNCATED & N/A & RBVO01000003.1; pos. 835 to 1273 & pos. 6751 to 7148 \\
\hline $\operatorname{ugp} Q$ & Glycerophosphoryl diester phosphodiesterase-like protein & FORWARD & MW0029 & RBVO01000003.1; pos. 1474 to 2218 & pos. 7350 to 8093 \\
\hline ydeM & Acyl dehydratase MaoC & FORWARD & MW0030 & RBVO01000003.1; pos. 2314 to 2743 & pos. 8190 to 8618 \\
\hline mecA & Encodes penicillin binding protein 2 prime, defining MRSA & REVERSE & MW0031 & RBVO01000003.1; pos. 2812 to 4795 & pos. 8664 to 10670 \\
\hline mecRI-trunc & $\begin{array}{l}\text { Methicillin resistance operon repressor } 1 \text {, signal transducer protein, truncated in } \\
\text { SCCmec IV }\end{array}$ & TRUNCATED & MW0032 & RBVO01000003.1; pos. 4894 to 5862 & pos. 10770 to 10816 \\
\hline hsdR2-IS1272 & Type I site-specific deoxyribonuclease restriction subunit & TRUNCATED & MW0033 & RBVO01000003.1; pos. 5869 to 6103 & pos. 11745 to 11978 \\
\hline tnpIS1272 & Transposase & REVERSE & MW0034 & RBVO01000003.1; pos. 6103 to 7627 & pos. 11979 to 13502 \\
\hline Q9KX75 & Hypothetical protein & REVERSE & MW0035 & RBVO01000003.1; pos. 7762 to 8269 & pos. 13638 to 14144 \\
\hline Q7A207 & Hypothetical protein & REVERSE & MW0036 & RBVO01000003.1; pos. 8283 to 8595 & pos. 14159 to 14470 \\
\hline Q7A206-trunc & Hypothetical protein, truncated & TRUNCATED & N/A & RBVO01000003.1; pos. 8596 to 8683 & pos. 14472 to 14558 \\
\hline Q7A206 & Hypothetical protein & REVERSE & MW0037 & RBVO01000003.1; pos. 8681 to 9032 & pos. 14557 to 14907 \\
\hline UTR_ccrB-2 & Highly conserved 3'-untranslated region of $c c r B$ & & N/A & RBVO01000003.1; pos. 9032 to 9553 & pos. 14908 to 15428 \\
\hline ccrB-2 & Cassette chromosome recombinase B2 & REVERSE & MW0038 & RBVO01000003.1; pos. 9553 to 11182 & pos. 15429 to 17057 \\
\hline ccrA-2 & Cassette chromosome recombinase $\mathrm{A} 2$ & REVERSE & MW0039 & RBVO01000003.1; pos. 11203 to 12553 & pos. 17079 to 18428 \\
\hline cch-2 & Hypothetical protein/cassette chromosome helicase & REVERSE & MW0040 & RBVO01000003.1; pos. 12786 to 14574 & pos. 18662 to 20449 \\
\hline DUF1413 & Hypothetical protein, associated with $c c h$ & REVERSE & MW0041 & RBVO01000003.1; pos. 14573 to 14864 & pos. 20449 to 20739 \\
\hline Q2FKL7 & Putative membrane protein & FORWARD & MW0042 & RBVO01000003.1; pos. 15002 to 16052 & pos. 20878 to 21927 \\
\hline Q8VUV8 & Putative transcriptional regulator & FORWARD & MW0043 & RBVO01000003.1; pos. 16504 to 17995 & pos. 22380 to 23870 \\
\hline cstB-scc2 & Includes a putative beta-lactamase; marker for SCCmec IVa & TRUNCATED & MW0045 & RBVO01000003.1; pos. 18367 to 19685 & pos. 24243 to 25560 \\
\hline Q2FKL3 & HNH endonuclease family protein & FORWARD & MW0046 & RBVO01000003.1; pos. 19875 to 20247 & pos. 25751 to 26122 \\
\hline Q8VUW0 & Putative membrane protein & FORWARD & MW0047 & RBVO01000003.1; pos. 20375 to 20996 & pos. 26251 to 26871 \\
\hline DR_SCC & Direct repeat of SCC & & N/A & RBVO01000003.1; pos. 21300 to 21319 & pos. 27176 to 27194 \\
\hline
\end{tabular}


Figure 1: Graphic representation of the SCCmec elements in the CC1 reference sequence MW2 (GenBank BA000033.23), in the European CC1MRSA-IV isolate Iasi-95037 (GenBank submission pending) and in the S. epidermidis isolate P11PPP12 (GenBank MH188467.1).

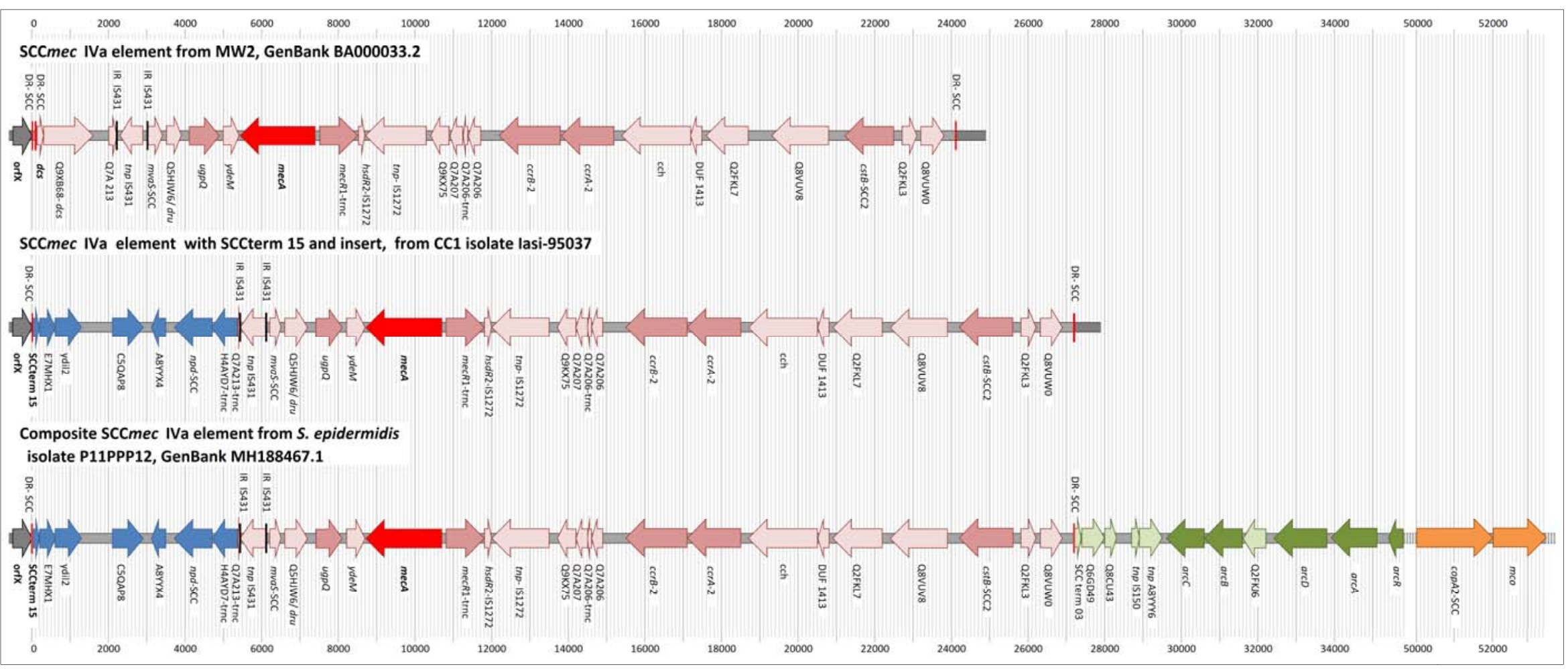


medRxiv preprint doi: https://doi.org/10.1101/2020.04.28.20083048; this version posted May 5, 2020. The copyright holder for this preprint (which was not certified by peer review) is the author/funder, who has granted medRxiv a license to display the preprint in perpetuity. It is made available under a CC-BY-NC-ND 4.0 International license.

\section{DISCUSSION}

The study demonstrates that a CC1-MRSA-IV strain prevalent in Europe can yield falsenegative results with frequently used commercial MRSA assays (GenXpert MRSA/SA BC and BD MAX Staph SR). Interestingly, CC1-MRSA-IV strains yielded correctly positive results when using the GeneXpert MRSA/SA SSTI, indicating that the tests are not equipped with the same primers and/or that there is already an updated version for one MRSA test available from Cepheid. Unfortunately, this is not the case for the blood culture (MRSA/SA BC) version that is primarily used for diagnosis in invasive infections. The primers used in these commercial tests are not disclosed, however, the absence of $d c s$ and the presence of a large insert in the region downstream of $\operatorname{orf} X$ correlate with negative GenXpert MRSA/SA $\mathrm{BC}$ test and BDmax results. It can therefore be assumed that the diverging results of the assays are related to their coverage of a sequence fragment alternate to dcs (SCCterm 15; see Table 2 and Figure 1).

This sequence (SCCterm 15) has previously been observed in at least three different S. aureus strains (for discussion of S. epidermidis, see below). In CC152-MRSA-XIII, SCCterm 15 is located adjacent to $\operatorname{orfX}$ (GenBank MG674089, CP024998; (23)) and thus, may affect MSRA assays spanning the orf X/SCCmec junction. For the remaining two strains, this sequence is situated away from orfX, within complex composite SCCmec elements. One of these strains is a Danish CC8-MRSA strain (24) with an SCCmec IVa/ACME composite element (e.g., Strain M1, GenBank HM030720.1). In this strain, the same insert as in the "European CC1" strain is localised at the boundary between an ACME-II element and an SCCmec element (25). Here, SCCterm 15 is not adjacent to $\operatorname{orf} X$, and the negative junction site PCR results observed can be attributed to yet another SCCterm sequence. Another, CC22-MRSA, strain (CMFT3119, GenBank HF569105.1) from Saudi Arabia also harboured SCCterm 15, E7MHX1, ydiL2, 
medRxiv preprint doi: https://doi.org/10.1101/2020.04.28.20083048; this version posted May 5, 2020. The copyright holder for this preprint (which was not certified by peer review) is the author/funder, who has granted medRxiv a license to display the preprint in perpetuity. It is made available under a CC-BY-NC-ND 4.0 International license.

IR_IS431 and tnpIS431 localised between a copper resistance element and a composite element encompassing ACME-II and SCCmec IVh/j (26).

SCCterm 15, E7MHX1, ydiL2, C5QAP8, A8YYX4, npd and H4AYD7 are also present in $S$. epidermidis P11PPP12 (GenBank MH188467.1), suggesting a transfer of this region between coagulase-negative staphylococci and CC1 S. aureus. Beyond these genes, the entire SCCmec IV element of P11PPP12 is identical to that in the CC1-MRSA strain. Most significantly, the fault line cutting short Q7A213 is conserved in both strains (position 5818/5819 in Supplemental file S1), suggesting it unlikely that the insert alone was transferred from a P11PP12-like ancestor into S. aureus CC1. Indeed, it is more likely that the entire variant SCCmec IVa cassette (including the insert) was transferred between the ancestors of the two strains, although the direction of this transfer remains unknown. P11PPP12 also harbours an ACME-II element downstream of SCCmec IVa, which comprises another SCC terminal sequence (as in FR753166.1, pos. 481-568), arc genes, another copy of tnpIS431, and heavy metal resistance genes. ACME-II is absent from the European CC1-MRSA-IV clone. Therefore, either it must have been lost during or after transfer of the SCC element between $S$. epidermidis and $\mathrm{CC} 1$, or it was later acquired by ancestors of $S$. epidermidis P11PPP12. Most likely, the MRSA emerged following transfer of an "atypical" (dcs-negative) SCCmec IVa element from coagulase-negative staphylococci into a CC1-MSSA strain that is prevalent in South-Eastern Europe.

The presence of MRSA that are negative in orfX/SCCmec junction site PCRs provides reasons for concern. Firstly, molecular assays are used to predict a presence of MRSA in positive blood cultures and, hence, to prompt administration antibiotics that cover MRSA. A false negative result would harm the patient by delaying effective therapy until conventional susceptibility test results become available. This could easily have fatal consequences. The use of molecular assays for the guidance of therapy in life-threatening circumstances is 
medRxiv preprint doi: https://doi.org/10.1101/2020.04.28.20083048; this version posted May 5, 2020. The copyright holder for this preprint (which was not certified by peer review) is the author/funder, who has granted medRxiv a license to display the preprint in perpetuity. It is made available under a CC-BY-NC-ND 4.0 International license .

beneficial for a vast majority of patients due to speed. However, these assays can only detect target sequences that were considered upon primer design. Conventional susceptibility tests are slower but they are not constrained by the choice of primers or by the presence of unknown or unexpected genotypes. Thus, they must not be neglected and should be carried out in parallel to molecular assays.

Secondly, molecular assays are used to guide IPC. A false negative result may result in failure to isolate an infected patient and further spread of the strain. Regarding IPC, it is also noteworthy that this strain can harbour plasmid-borne genes qacA and ileS2/mupR (14), encoding resistance to quaternary ammonium compounds, biguanides and mupirocin, with the latter compounds commonly being recommended for MRSA decolonisation (27). Thus, it may not only escape detection by molecular screening, but also circumvent decolonisation.

A third and less obvious consequence is a potential shift in the clonal structure of local MRSA population with molecular assays themselves providing a selective pressure favouring the false-negative strain. Other strains will get "penalised" for being PCR-positive as subsequent interventions would hinder their proliferation and transmission. In the long term, this would lead to a higher prevalence of the false-negative strain, and increasingly more therapy and IPC failures.

As previously discussed, the European CC1-MRSA-IV clone may have emerged in SouthEastern Europe. A putative methicillin-susceptible ancestor is common in Romania where the MRSA strain was early and frequently observed $(14,17)$. Significant case numbers have been reported from Bavaria (14), North Rhine-Westphalia (28), Italy (29) and Ireland (14). Sporadic cases have been described in Austria (30) and Saxony (11).

A strategy to contain the $\mathrm{CC} 1$ strain must rely on conventional susceptibility tests or updated molecular tests. We therefore propose to screen, at least, patients with conspicuous travel histories as well as medical or nursing staff recruited in epidemic regions, not only by 
medRxiv preprint doi: https://doi.org/10.1101/2020.04.28.20083048; this version posted May 5, 2020. The copyright holder for this preprint

(which was not certified by peer review) is the author/funder, who has granted medRxiv a license to display the preprint in perpetuity.

It is made available under a CC-BY-NC-ND 4.0 International license.

Page 21

molecular means but also by culture of nasal swabs on selective growth media. Sequence information and isolates described herein can be used by test manufacturers to adapt future versions of their assays in order to identify this strain.

The problem of unknown or unexpected genotypes also represents a considerable economic risk for the manufacturer of molecular point-of-care tests. The staging and approval of CEmarked in vitro diagnostic tests is very expensive and time-consuming, while there is an absolute necessity to adapt tests to constant evolution of targeted pathogens. It is therefore important for the manufacturers to be able to integrate new markers or new sequence variants into existing tests and platforms with minimal regulatory and economic effort. Unfortunately, the European Commission's new In Vitro Diagnostic Regulation (IVDR 2017/746) will further raise the regulatory burden (from 2022 on), which may discourage companies from frequently updating assays. Thus, this regulation might, paradoxically, endanger the patients it was intended to protect.

Finally, it is crucial to monitor the emergence of new SCCmec junction sites in staphylococci, both in S. aureus and coagulase-negative staphylococci, as mobile SCCmec elements can be readily transmitted between different strains and species, as was the case in the strain described herein. It is imperative that companies that offer rapid tests should react to these changes and adapt their products to the market as quickly as possible. 
medRxiv preprint doi: https://doi.org/10.1101/2020.04.28.20083048; this version posted May 5, 2020. The copyright holder for this preprint (which was not certified by peer review) is the author/funder, who has granted medRxiv a license to display the preprint in perpetuity.

It is made available under a CC-BY-NC-ND 4.0 International license .

Page 22

\section{AUTHORS' CONTRIBUTIONS}

Stefan Monecke: Conception and design of the study, data visualisation, analysis and interpretation of data, drafting of the manuscript

Elisabeth König: Collection of strains and data generation, analysis and interpretation of data

Megan R. Earls: Data generation, analysis and interpretation of data; drafting of the manuscript

Eva Leitner: Conception and design of the study, data generation, analysis and interpretation of data, drafting of the manuscript

Elke Müller: Data generation, analysis and interpretation of data

Gabriel Wagner: Data generation, analysis and interpretation of data

David Poitz: Data generation, analysis and interpretation of data

Lutz Jatzwauk: Data generation, analysis and interpretation of data

Teodora Vremeră: Collection of strains and data generation

Olivia S. Dorneanu: Collection of strains and data generation

Alexandra Simbeck: Collection of strains and data generation, analysis and interpretation of data

Andreas Ambrosch: Data generation, analysis and interpretation of data

Ines Zollner-Schwetz: Data generation, analysis and interpretation of data

Robert Krause: Data generation, analysis and interpretation of data

Werner Ruppitsch: Data generation, analysis and interpretation of data

Wulf Schneider: Data generation, analysis and interpretation of data

David C. Coleman: Analysis and interpretation of data; drafting of the manuscript

Ivo Steinmetz: Analysis and interpretation of data; drafting of the manuscript

Ralf Ehricht: Conception and design of the study, analysis and interpretation of data; drafting of the manuscript

\section{ACKNOWLEDGMENTS}

DC and ME wish to acknowledge the support of the staff of the Irish National MRSA

Reference Laboratory at St. James's Hospital, Dublin, Ireland.

\section{COMPETING INTEREST}

Not applicable.

\section{ETHICS APPROVAL AND CONSENT TO PARTICIPATE}

Not applicable.

\section{FUNDING}

There was no external funding for this study. 


\section{REFERENCES}

1. Shore AC, Deasy EC, Slickers P, Brennan G, O'Connell B, Monecke S, et al. Detection of staphylococcal cassette chromosome mec type XI carrying highly divergent mecA, mecI, mecR1, blaZ, and ccr genes in human clinical isolates of clonal complex 130 methicillinresistant Staphylococcus aureus. Antimicrob Agents Chemother. 2011;55(8):3765-73.

2. Garcia-Alvarez L, Holden MT, Lindsay H, Webb CR, Brown DF, Curran MD, et al. Meticillin-resistant Staphylococcus aureus with a novel mecA homologue in human and bovine populations in the UK and Denmark: a descriptive study. Lancet Infect Dis. 2011;11(8):595-603.

3. Monecke S, Gavier-Widen D, Mattsson R, Rangstrup-Christensen L, Lazaris A, Coleman DC, et al. Detection of mecC-positive Staphylococcus aureus (CC130-MRSA-XI) in diseased European hedgehogs (Erinaceus europaeus) in Sweden. PLoS ONE. 2013;8(6):e66166.

4. Rasmussen SL, Larsen J, van Wijk RE, Jones OR, Berg TB, Angen Ø, et al. European hedgehogs (Erinaceus europaeus) as a natural reservoir of methicillin-resistant Staphylococcus aureus carrying mecC in Denmark. PLoS ONE. 2019;14(9):e0222031.

5. Bengtsson B, Persson L, Ekström K, Unnerstad HE, Uhlhorn H, Börjesson S. High occurrence of mecC-MRSA in wild hedgehogs (Erinaceus europaeus) in Sweden. Vet Microbiol. 2017;207:103-7.

6. Becker K, van Alen S, Idelevich EA, Schleimer N, Seggewiss J, Mellmann A, et al. Plasmid-Encoded Transferable mecBMediated Methicillin Resistance in Staphylococcus aureus. Emerg Infect Dis. 2018;24(2):242-8.

7. Schwendener S, Cotting K, Perreten V. Novel methicillin resistance gene mecD in clinical Macrococcus caseolyticus strains from bovine and canine sources. Scientific Reports. 2017;7(1):43797.

8. Xu Z, Hou Y, Peters BM, Chen D, Li B, Li L, et al. Chromogenic media for MRSA diagnostics. Molecular Biology Reports. 2016;43(11):1205-12.

9. van Belkum A, Rochas O. Laboratory-Based and Point-of-Care Testing for MSSA/MRSA Detection in the Age of Whole Genome Sequencing. Frontiers in Microbiology. 2018;9(1437).

10. Shore AC, Rossney AS, O'Connell B, Herra CM, Sullivan DJ, Humphreys H, et al. Detection of staphylococcal cassette chromosome mec-associated DNA segments in multiresistant methicillin-susceptible Staphylococcus aureus (MSSA) and identification of Staphylococcus epidermidis ccrAB4 in both methicillin-resistant S. aureus and MSSA. Antimicrob Agents Chemother. 2008;52(12):4407-19.

11. Monecke S, Jatzwauk L, Muller E, Nitschke H, Pfohl K, Slickers P, et al. Diversity of SCCmec elements in Staphylococcus aureus as observed in South-Eastern Germany. PLoS ONE. 2016;11(9):e0162654.

12. Sharff KA, Monecke S, Slaughter S, Forrest G, Pfeiffer C, Ehricht R, et al. Genotypic Resistance Testing Creates New Treatment Challenges: Two Cases of Oxacillin-Susceptible Methicillin-Resistant Staphylococcus aureus. Journal of Clinical Microbiology. 2012;50(12):4151-3.

13. Earls MR, Kinnevey PM, Brennan GI, Lazaris A, Skally M, O'Connell B, et al. The recent emergence in hospitals of multidrug resistant community-associated sequence type 1 and spa type t127 methicillin-resistant Staphylococcus aureus investigated by wholegenome sequencing: Implications for screening. PLoS ONE. 2017;12(4):e0175542.

14. Earls MR, Shore AC, Brennan GI, Simbeck A, Schneider-Brachert W, Vremeră T, et al. A novel multidrug-resistant PVLnegative CC1-MRSA-IV clone emerging in Ireland and Germany likely originated in South-Eastern Europe. Infection, Genetics and Evolution. 2019;69:117-26

15. EUCAST. EUCAST rapid antimicrobial susceptibility testing (RAST) directly from positive blood culture bottles. . 2018.

16. EUCAST. Zone diameter breakpoints for rapid antimicrobial susceptibility testing (RAST) directly from blood culture bottles. Version 1.1. 2019.

17. Monecke S, Müller E, Dorneanu OS, Vremeră T, Ehricht R. Molecular typing of MRSA and of clinical Staphylococcus aureus isolates from Ia $\square$ i, Romania. PLoS ONE. 2014;9(5):e97833.

18. Monecke S, Coombs G, Shore AC, Coleman DC, Akpaka P, Borg M, et al. A field guide to pandemic, epidemic and sporadic clones of methicillin-resistant Staphylococcus aureus. PLoS ONE. 2011;6(4):e17936.

19. Earls MR, Coleman DC, Brennan GI, Fleming T, Monecke S, Slickers P, et al. Intra-Hospital, Inter-Hospital and Intercontinental Spread of ST78 MRSA From Two Neonatal Intensive Care Unit Outbreaks Established Using Whole-Genome Sequencing. Frontiers in Microbiology. 2018;9(1485).

20. Chen S, Zhou Y, Chen Y, Gu J. fastp: an ultra-fast all-in-one FASTQ preprocessor. Bioinformatics. 2018;34(17):i884-i90.

21. Bankevich A, Nurk S, Antipov D, Gurevich AA, Dvorkin M, Kulikov AS, et al. SPAdes: a new genome assembly algorithm and its applications to single-cell sequencing. J Comput Biol. 2012;19(5):455-77.

22. Howden BP, Beaume M, Harrison PF, Hernandez D, Schrenzel J, Seemann T, et al. Analysis of the small RNA transcriptional response in multidrug-resistant Staphylococcus aureus after antimicrobial exposure. Antimicrobial agents and chemotherapy. 2013;57(8):3864-74 
medRxiv preprint doi: https://doi.org/10.1101/2020.04.28.20083048; this version posted May 5, 2020. The copyright holder for this preprint (which was not certified by peer review) is the author/funder, who has granted medRxiv a license to display the preprint in perpetuity.

It is made available under a CC-BY-NC-ND 4.0 International license .

Page 24

23. Baig S, Johannesen TB, Overballe-Petersen S, Larsen J, Larsen AR, Stegger M. Novel SCCmec type XIII (9A) identified in an ST152 methicillin-resistant Staphylococcus aureus. Infection, Genetics and Evolution. 2018;61:74-6.

24. Bartels MD, Boye K, Rohde SM, Larsen AR, Torfs H, Bouchy P, et al. A common variant of staphylococcal cassette chromosome mec type IVa in isolates from Copenhagen, Denmark, is not detected by the BD GeneOhm methicillin-resistant Staphylococcus aureus assay. J Clin Microbiol. 2009;47(5):1524-7.

25. Bartels MD, Hansen LH, Boye K, Sørensen SJ, Westh H. An Unexpected Location of the Arginine Catabolic Mobile Element (ACME) in a USA300-Related MRSA Strain. PLoS ONE. 2011;6(1):e16193.

26. Hill-Cawthorne GA, Hudson LO, El Ghany MFA, Piepenburg O, Nair M, Dodgson A, et al. Recombinations in staphylococcal cassette chromosome mec elements compromise the molecular detection of methicillin resistance in Staphylococcus aureus. PLoS ONE. 2014;9(6):e101419.

27. Poovelikunnel T, Gethin G, Humphreys H. Mupirocin resistance: clinical implications and potential alternatives for the eradication of MRSA. Journal of Antimicrobial Chemotherapy. 2015;70(10):2681-92.

28. Scheithauer S, Trepels-Kottek S, Häfner H, Keller D, Ittel T, Wagner N, et al. Healthcare worker-related MRSA cluster in a German neonatology level III ICU: A true European story. International Journal of Hygiene and Environmental Health. 2014;217(2):307-11.

29. Manara S, Pasolli E, Dolce D, Ravenni N, Campana S, Armanini F, et al. Whole-genome epidemiology, characterisation, and phylogenetic reconstruction of Staphylococcus aureus strains in a paediatric hospital. Genome Medicine. 2018;10(1):82.

30. Loncaric I, Stalder GL, Mehinagic K, Rosengarten R, Hoelzl F, Knauer F, et al. Comparison of ESBL--and AmpC producing Enterobacteriaceae and methicillin-resistant Staphylococcus aureus (MRSA) isolated from migratory and resident population of rooks (Corvus frugilegus) in Austria. PLoS ONE. 2013;8(12):e84048.

\section{SUPPLEMENTS}

Supplemental File S1: Alignment of the SCCmec elements of study isolates, reference strains and the individual SCC-associated genes.

Supplemental File S2: Sequence of the SCCmec element of study isolate Iasi-95037 (GenBank MT380478, submission being processed) 